\title{
The effect of folate analogues on thymidine utilization by human and rat marrow cells and the effect on the deoxyuridine suppression test
}

\author{
ROSEMARY DEACON \\ F.I.M.L.S. \\ I. ChANARIN \\ M.D., F.R.C.Path. \\ JANET PERRY \\ B.Sc., Ph.D. \\ M. LUMB \\ A.I.M.L.S. \\ M.R.C. Clinical Research Centre, Northwick Park Hospital, Harrow, Middlesex
}

\begin{abstract}
Summary
The deoxyuridine (dU) suppression test assesses the capacity of marrow cells or activated lymphocytes to convert exogenous dU into thymidine. In addition, the effect of the added cobalamin or folate on the result is used to determine the nature of the deficiency in megaloblastic marrows. This study shows that folates have a considerable effect on the uptake of labelled thymidine by marrows from patients with megaloblastic anaemia in the absence of added dU. Less thymidine was taken up by megaloblastic marrow cells if they were first incubated with 5-formyltetrahydrofolate, 10-formyltetrahydrofolate or tetrahydrofolate. 5-Methyltetrahydrofolate increased thymidine uptake in cobalamin-deficient marrows and reduced thymidine uptake in folate-deficient marrows. These results could be explained if added folates facilitated utilization of endogenous dU. However, the addition of folates or cobalamin did not affect the validity of a dU suppression test with human marrow. More marked changes were present on the addition of folates to rat marrow cells both from control and nitrous oxidetreated animals.
\end{abstract}

\section{Introduction}

Thymidine synthesis is impaired in cells from patients with untreated megaloblastic anaemia. At a biochemical level there is depressed conversion of deoxyuridine (dU) to deoxythymidine. Both folate and cobalamin are required for this step which involves the transfer of a single-carbon unit $\left(-\mathrm{CH}_{2}\right.$ or methylene) from methylenetetrahydrofolate to dU. During this transfer, by thymidylate synthetase, the methylene group is reduced to methyl $\left(-\mathrm{CH}_{3}\right)$. The $\mathrm{dU}$ suppression test performed on marrow samples tests this step by noting first, how the cells use $\mathrm{dU}$ to make thymidine and, subsequently, if their thymidine requirements have not been met from dU, how much preformed labelled thymidine they are able to use (Killman, 1964; Metz et al., 1968). If the marrow cells are able to convert dU into thymidine effectively very little of the exogenous thymidine will be used. Cells that do not use $\mathrm{dU}$ normally will take up larger amounts of added labelled thymidine. Experience indicates that the test is abnormal in almost all patients with megaloblastic anaemia (Chanarin, 1979). The defect is corrected on the addition of cobalamin to marrow from cobalamin-deficient patients and the result is improved in all megaloblastic marrows on the addition of most folate compounds.

Studies using marrow from rats, both controls and animals in which cobalamin had been inactivated by nitrous oxide, made it possible to test a much wider range of folate analogues (Deacon et al., 1980). The results indicated that in the rat, addition of formylfolates were much more effective in overcoming the block produced by $\mathrm{B}_{12}$ inactivation than other folates and that the result could be significantly affected by the addition of folate to the control tube (lacking dU). Bain (1975) and Rogers and Lietman (1977) showed that the addition of folate to the culture medium reduced uptake of ${ }^{3} \mathrm{H}$-thymidine by stimulated lymphocytes. Wickramasinghe and Saunders (1979) reported lower dU values in 2 out of 8 tests when additions of vitamins were made to the control tube. Apart from this paper this aspect has not received a great deal of attention in interpreting data from the $\mathrm{dU}$ suppression tests.

The purpose of this study was to explore the effect on thymidine requirements of adding folate analogues to marrow from megaloblastic patients and control subjects and, secondly, to assess the effect of such modified controls on the results of the dU suppression test. Similar studies were made with rat marrow both from control and $\mathrm{N}_{2} \mathrm{O}$-treated animals.

\section{Materials and methods \\ Patients studied}

Marrow samples were obtained from 11 patients with untreated megaloblastic anaemia, 6 due to pernicious anaemia and 5 to folate deficiency. In 
addition, observations were made on 4 marrows from haematologically normal patients. These had been requested as part of the investigation of the patient.

\section{Animals}

Male, Sprague-Dawley, $80-$ to $120-\mathrm{g}$ rats were placed in a chamber in which a mixture of $\mathrm{N}_{2} \mathrm{O}$ $(50 \%)$ and oxygen $(50 \%)$ was passed, and $\mathrm{CO}_{2}$ and humidity controlled. After $3 \mathrm{hr}$ the animals were killed by exsanguination preceded by an injection of sodium pentobarbitone, long bones removed, split with a scalpel and marrow washed into $5 \mathrm{ml}$ cold Hanks's balanced salt solution (BSS) (pH 7.2-7.4) containing $0.5 \mathrm{ml}$ preservative-free heparin (1000 i.u./ml). Control animals were left in air.

\section{Marrow}

The marrow collected in Hanks's solution was passed through 21- and 25-gauge needles to break up clumps and washed in cold Hanks's BSS. The cells were then resuspended in a known volume of Hanks's BSS containing $10 \%$ rat or $20 \%$ human serum. A cell count was performed and volume adjusted so that there were between $1.5 \times 10^{6}$ and $7 \times 10^{6}$ cells $/ \mathrm{ml}$.

\section{Deoxyuridine suppression test}

In this test a marrow cell suspension is incubated with $\mathrm{dU}$. This is normally converted into thymidine which in turn is incorporated into DNA. At a second stage $\left[{ }^{3} \mathrm{H}\right]$ thymidine is added so that any requirement not met by synthesis from dU is met by utilization of $\left[{ }^{3} \mathrm{H}\right]$ thymidine. A $100 \%$ value is obtained by incubating marrow with $\left[{ }^{3} \mathrm{H}\right]$ thymidine directly without preceding $\mathrm{dU}$. The result is expressed as

$$
\frac{\left[{ }^{3} \mathrm{H}\right] \text { thymidine uptake after } \mathrm{dU} \times 100}{\left[{ }^{3} \mathrm{H}\right] \text { thymidine uptake alone }} .
$$

Normal rat or human marrow cells meet more than $90 \%$ of their thymidine requirements from dU so that less than $10 \%$ of $\left[{ }^{3} \mathrm{H}\right]$ thymidine is used.
Tests and controls were set up in duplicate. One-mo marrow suspension was added to each tube followed by $10 \mu \mathrm{l}$ of the additive (cobalamin and/or a folate analogue) and the tubes incubated at $37^{\circ} \mathrm{C}$ foop $15 \mathrm{~min}$. Deoxyuridine (Sigma) $0.33 \mu \mathrm{mol}$ in $10 \mu d$ saline was added to one set of tubes and incubatio at $37^{\circ} \mathrm{C}$ continued for $15 \mathrm{~min}$. $\left[{ }^{3} \mathrm{H}\right]$ thymidin $(1 \mu \mathrm{Ci} / 0 \cdot 2 \mathrm{nmol})$ (Amersham) in $100 \mu \mathrm{l}$ saline was added to all tubes and incubated for $60 \mathrm{~min}$. The cells were washed twice in cold phosphate buffere saline, $2 \mathrm{ml}$ cold $0.5 \mathrm{M}$ perchloric acid added to the cell pellet and left in ice for $10 \mathrm{~min}$. The supernatant was decanted and DNA extracted in $0.5 \mathrm{ml} 0.5$ 岱 perchloric acid for $20 \mathrm{~min}$ at $80^{\circ} \mathrm{C}$.

$\left[{ }^{3} \mathrm{H}\right]$ thymidine was measured in $100 \mu \mathrm{l}$ of the clea extract by liquid scintillation, appropriate correction. being made by quenching.

\section{$\left[{ }^{3} \mathrm{H}\right]$ thymidine uptake alone}

The tests consisted of duplicate tubes, one set containing marrow cells and thymidine and the other set the additive (see below), marrow cells and thymidine. Volumes of reagents, incubation and processing was as for the $\mathrm{dU}$ suppression test.

\section{Solutions}

The following were added in the dU suppressigom test and in the thymidine uptake study: hydroxos cobalamin $(\mathrm{OHCbl}) 1 \mathrm{mg} / \mathrm{ml}$, DL 5-CHO- $\mathrm{H}_{4} \mathrm{Pte}$ बil (Lederle) $3 \mathrm{mg} / \mathrm{ml}$, PteGlu $1.5 \mathrm{mg} / \mathrm{ml}$, DL $5-\mathrm{CH}_{3 \xi}$ $\mathrm{H}_{4}$ PteGlu (Sigma) $3 \mathrm{mg} / \mathrm{ml}$ in $0.1 \mathrm{M}$ potassiun phosphate buffer $\mathrm{pH} 7.0$ to which was added $10 \mathrm{~mm}$ 2-mercaptoethanol, DL $\mathrm{H}_{4}$ PteGlu (Sigma) $3 \mathrm{mg} / \mathrm{mo}$ in $1 \%$ potassium ascorbate $\mathrm{pH} 6.5$ stored unde? nitrogen, $10-\mathrm{CHO}-\mathrm{H}_{4} \mathrm{PteGlu} 3 \mathrm{mg} / \mathrm{ml}$ prepare $\bar{\Phi}$ from 5-CHO-H ${ }_{4}$ PteGlu (Sigma) by the method of Rabinowitz (1963) in $1 \%$ potassium ascorbate $\mathrm{pH}$ 要 and kept under nitrogen.

\section{Results}

The effect of ascorbate, 2-mercaptoethanol and buffe solution on $\left[{ }^{3} \mathrm{H}\right]$ thymidine uptake by marrow

These reagents were required to maintain the

TABLE 1. Key to formulae used in this paper

\begin{tabular}{ll}
\hline Formulae & Substance \\
\hline $\mathrm{F}(\mathrm{PteGlu})$ & folic acid (pteroylglutamic acid) \\
$5-\mathrm{CHO}-\mathrm{H}_{4} \mathrm{~F}$ & 5-formyltetrahydrofolate \\
$10-\mathrm{CHO}-\mathrm{H}_{4} \mathrm{~F}$ & 10-formyltetrahydrofolate \\
$\mathrm{OH}-\mathrm{Cbl}$ & hydroxocobalamin \\
$\mathrm{OH}-\mathrm{Cbl}+5-\mathrm{CHO}-\mathrm{H}_{4} \mathrm{~F}$ & hydroxocobalamin +5 -formyltetrahydrofolate \\
$\mathrm{OH}-\mathrm{Cbl}+10-\mathrm{CHO}-\mathrm{H}_{4} \mathrm{~F}$ & hydroxocobalamin + 10-formyltetrahydrofolate \\
$\mathrm{OH}-\mathrm{Cbl}+5-\mathrm{CH}_{3}-\mathrm{H}_{4} \mathrm{~F}$ & hydroxocobalamin +5 -methyltetrahydrofolate \\
$\mathrm{OH}-\mathrm{Cbl}+\mathrm{H}_{4} \mathrm{~F}$ & hydroxocobalamin + tetrahydrofolate \\
$5-\mathrm{CH}_{3}-\mathrm{H}_{4} \mathrm{~F}$ & 5-methyltetrahydrofolate \\
$\mathrm{H}_{4} \mathrm{~F}$ & tetrahydrofolate \\
\hline
\end{tabular}


stability of folate analogues used in these studies. One per cent. ascorbate $\mathrm{pH} 6.5$ had no effect in the $\mathrm{dU}$ suppression test using rat marrow, nor was there any effect produced by the buffer solution in which 10-CHO- $\mathrm{H}_{4}$ PteGlu was dissolved. However, the $0 \cdot 1 \mathrm{M}$ potassium phosphate buffer with 2 -mercaptoethanol used to preserve $5-\mathrm{CH}_{3}-\mathrm{H}_{4} \mathrm{PteGlu}$ had a significant effect on the result of the dU suppression test which fell from 10.9 and $10.5 \%$ to 8.4 and $6.9 \%$ in 2 tests respectively.

The effect of cobalamin and/or folate analogues on $\left[{ }^{3} \mathrm{H}\right]$ thymidine uptake by marrow cells

In these studies, $\mathrm{B}_{12}$ and/or folate were first added to marrow suspensions followed by $\left[{ }^{3} \mathrm{H}\right]$ thymidine. $B_{12}$ or folate were omitted from a second set of tubes to which thymidine alone was added. These served as controls. In each study the uptake of $\left[{ }^{3} \mathrm{H}\right]$ thymidine in the control $(100 \%)$ was compared with that in the presence of the additive.

There were significant reductions of thymidine uptake after the additions of tetrahydrofolate and its 10-formyl derivative to rat marrow $(P>0.001)$ (Table 2). Results of individual experiments in control rats are shown in Fig. 1. Generally similar results were obtained on control and $\mathrm{N}_{2} \mathrm{O}$-treated rats (with the exception of $10-\mathrm{CHO}-\mathrm{H}_{4} \mathrm{PteGlu}$ ) and the effects were more severe when both $\mathrm{B}_{12}$ and folate analogues were added together.

By contrast the addition of methylfolate enhanced the uptake of thymidine.

Data using normal human marrow cells (Table 3 and Fig. 2) show that folate analogues and hydroxocobalamin did not have any significant effect on the uptake of thymidine. Nor did $\mathbf{B}_{12}$ have any significant effect on cells from patients with megaloblastic anaemia due to either $B_{12}$ or folate deficiency. Folate analogues, however, had a highly significant effect. Tetrahydrofolate and its 5-formyl- and 10-formyl derivatives produced a fall in the amount of thymidine taken up. Methyltetrahydrofolate produced a significant fall in thymidine uptake in folate-deficient cells and a significant rise in uptake by $\mathrm{B}_{12}$-deficient cells. This difference was such that the addition of methylfolate followed by thymidine completely differentiated between the group due to $\mathrm{B}_{12}$ deficiency and that due to folate deficiency.

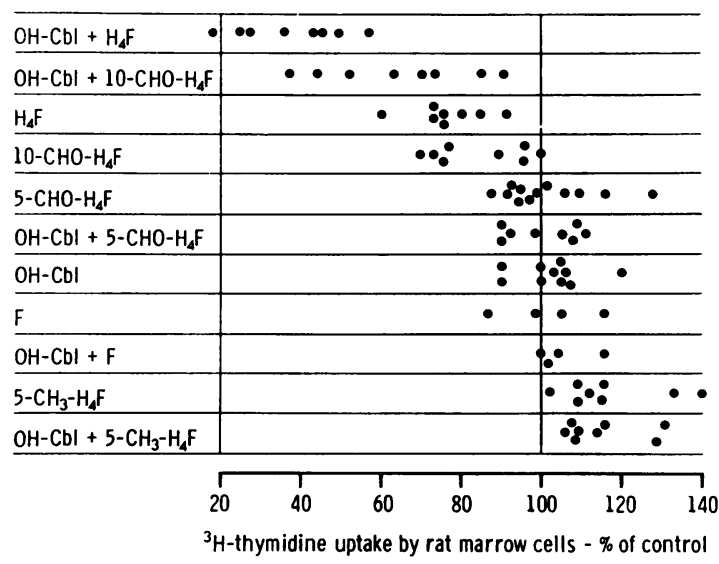

FIG. 1. Rat marrow cells were incubated with labelled thymidine alone (control) and after the addition of folate and/or hydroxocobalamin. The result is expressed as a percentage of thymidine uptake in the presence of $B_{12} /$ folate over thymidine uptake alone. Each point is the result of a single test performed in duplicate.

The effect of cobalamin/folate on the result of the deoxyuridine suppression test

Results of the dU suppression test using marrow from rats breathing air and breathing $\mathrm{N}_{2} \mathrm{O}$ /oxygen (1/1) are shown in Table 4 and Fig. 3. As reported elsewhere (Deacon et al., 1980), exposure to $\mathrm{N}_{2} \mathrm{O}$ impairs the synthesis of thymidine and hence the

TABLE 2. The effect of folates and/or cobalamin on the uptake of $\left[{ }^{3} \mathrm{H}\right]$ thymidine by marrow cells from air-breathing and $\mathrm{N}_{2} \mathrm{O}$-treated rats

$$
\frac{\text { Counts }\left[{ }^{3} \mathrm{H}\right] \text { thymidine }+ \text { additive } \times 100 \%}{\text { Counts with }\left[{ }^{3} \mathrm{H}\right] \text { thymidine alone }}
$$

\begin{tabular}{|c|c|c|c|c|c|c|}
\hline \multirow[b]{2}{*}{ Additive } & \multicolumn{3}{|c|}{ Air-breathing rats } & \multicolumn{3}{|c|}{$\mathrm{N}_{2} \mathrm{O}$-breathing rats } \\
\hline & No. & Mean & s.d. & No. & Mean & s.d. \\
\hline $\mathrm{OHCbl}$ & 10 & 103 & $8 \cdot 6$ & 8 & 96 & $6 \cdot 8$ \\
\hline $5-\mathrm{CHOH}_{4} \mathrm{~F}$ & 12 & 101 & $12 \cdot 4$ & 10 & 100 & $10 \cdot 7$ \\
\hline $\mathrm{H}_{4} \mathrm{~F}$ & 8 & 77* & $9 \cdot 4$ & 8 & 88* & $14 \cdot 7$ \\
\hline $10-\mathrm{CHOH}_{4} \mathrm{~F}$ & 8 & $84^{*}$ & $11 \cdot 6$ & 8 & 93 & $16 \cdot 9$ \\
\hline $5-\mathrm{CH}_{3} \mathrm{H}_{4} \mathrm{~F}$ & 8 & $117^{*}$ & $12 \cdot 9$ & 8 & $115^{*}$ & $13 \cdot 4$ \\
\hline $\mathbf{F}$ & 4 & 101 & $13 \cdot 8$ & 4 & 102 & $\mathbf{9 \cdot 9}$ \\
\hline $\mathrm{OHCbl}+5-\mathrm{CHOH}_{4} \mathrm{~F}$ & 8 & 101 & $8 \cdot 8$ & 8 & 105 & $15 \cdot 8$ \\
\hline $\mathrm{OHCbl}+\mathrm{H}_{4} \mathrm{~F}$ & 8 & $37^{*}$ & $13 \cdot 2$ & 8 & $57^{*}$ & $20 \cdot 1$ \\
\hline $\mathrm{OHCbl}+10-\mathrm{CHOH}_{4} \mathrm{~F}$ & 8 & $64^{*}$ & $19 \cdot 2$ & 8 & 79* & $23 \cdot 3$ \\
\hline $\mathrm{OHCbl}+5-\mathrm{CH}_{3} \mathrm{H}_{4} \mathrm{~F}$ & 8 & $115^{*}$ & $9 \cdot 9$ & 8 & $122 *$ & $22 \cdot 7$ \\
\hline $\mathrm{OHCbl}+\mathbf{F}$ & 4 & 106 & $7 \cdot 4$ & 4 & 98 & $14 \cdot 7$ \\
\hline
\end{tabular}

*Significant difference from control $(100 \%)$ value. 
TABLE 3. The effect of folates or cobalamin on the uptake of $\left[{ }^{3} \mathrm{H}\right]$ thymidine by marrow cells from control subjects and patients with cobalamin or folate deficiency

Counts $\left[{ }^{3} \mathrm{H}\right]$ thymidine + additive $\times 100 \%$

Counts with $\left[{ }^{3} \mathrm{H}\right]$ thymidine alone

\begin{tabular}{|c|c|c|c|c|c|c|c|c|c|}
\hline \multirow[b]{2}{*}{ Additive } & \multicolumn{3}{|c|}{ Controls } & \multicolumn{3}{|c|}{$\mathrm{B}_{12}$-deficiency } & \multicolumn{3}{|c|}{ Folate-deficiency } \\
\hline & No. & Mean & s.d. & No. & Mean & s.d. & No. & Mean & s.d. \\
\hline $\mathrm{OHCbl}$ & 4 & 97 & $14 \cdot 6$ & 6 & 94 & $8 \cdot 2$ & 5 & 91 & $10 \cdot 9$ \\
\hline $5-\mathrm{CHO}-\mathrm{H}_{4} \mathrm{~F}$ & 4 & 94 & $10 \cdot 9$ & 6 & $75^{*}$ & $14 \cdot 8$ & 5 & $80^{*}$ & $15 \cdot 9$ \\
\hline $10-\mathrm{CHO}-\mathrm{H}_{4} \mathrm{~F}$ & 4 & 101 & $5 \cdot 3$ & 6 & 74* & $18 \cdot 2$ & 5 & 78* & $16 \cdot 7$ \\
\hline $\mathrm{H}_{4} \mathrm{~F}$ & 4 & 102 & $4 \cdot 8$ & 6 & $85^{*}$ & $16 \cdot 4$ & 5 & $80^{*}$ & $13 \cdot 8$ \\
\hline $5-\mathrm{CH}_{3}-\mathrm{H}_{4} \mathrm{~F}$ & 4 & 103 & $10 \cdot 2$ & 5 & $121^{*}$ & $17 \cdot 6$ & 4 & $88^{*}$ & $3 \cdot 4$ \\
\hline
\end{tabular}

*Significant difference from control $(100 \%)$ value.

values in $\mathrm{N}_{2} \mathrm{O}$-breathing rats are all significantly higher than in controls. Further, correction of the defect is most effective when formylfolates are added to the incubation mixture. Nevertheless, the results are affected to a significant degree by the inclusion (B) or omission (A) of the additive to the control tubes. This affects both marrow from air-breathing as well as $\mathrm{N}_{2} \mathrm{O}$-breathing animals. Although the addition of folate to the tubes may alter the result it does not change the validity of the dU suppression test which remains either normal or abnormal under both sets of experimental conditions.

The addition of additives to both control and tests results in considerable uniformity of result in air breathing animals (column B) as opposed to the greater range in the absence of the additive (column A).

There were no significant differences in the results of the dU suppression test when this was carried out with and without the additives in the control tubes with normal human marrow, nor with marrow from

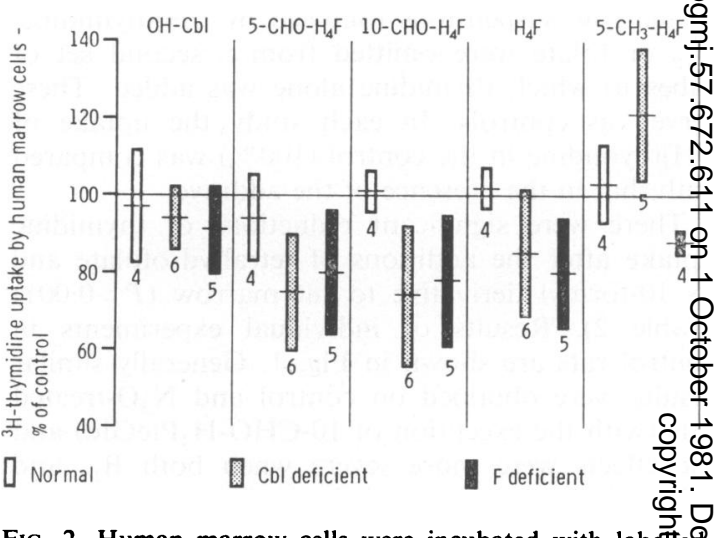

Fig. 2. Human marrow cells were incubated with labelle thymidine alone (control) and after the addition of either hydroxocobalamin or folate (F). The results are expressed as a percentage of thymidine uptake in the presence $\mathrm{B}_{12} /$ folate over thymidine uptake alone. The mean \pm s.d. shown for each group of patients and the number of patients is indicated below each column.

TABLE 4. Comparison of the result of the deoxyuridine suppression test in rat bone marrow with the addition of folate/ $B_{12}$ test only (A) and to standard and test (B)

Results as: counts with deoxyuridine $+\left[{ }^{3} \mathrm{H}\right]$ thymidine $\times 100$

\begin{tabular}{|c|c|c|c|c|c|c|c|c|c|c|c|c|}
\hline \multirow[b]{2}{*}{ Additive } & \multicolumn{6}{|c|}{ Air-breathing rats } & \multicolumn{6}{|c|}{$\mathrm{N}_{2} \mathrm{O}$-breathing rats } \\
\hline & No. & $\underset{\text { Mean }}{A}$ & s.d. & No. & $\underset{\text { Mean }}{\text { B }}$ & s.d. & No. & $\underset{\text { Mean }}{\text { A }}$ & s.d. & No. & $\underset{\text { Mean }}{\text { B }}$ & s.d. $\stackrel{ }{\jmath}$ \\
\hline Nil & 40 & $7 \cdot 3$ & $1 \cdot 59$ & & & & 21 & $15 \cdot 7$ & $2 \cdot 46$ & & & \\
\hline $\mathrm{OH}-\mathrm{Cbl}$ & 21 & $7 \cdot 7$ & $1 \cdot 54$ & 8 & $6 \cdot 8$ & $1 \cdot 62$ & 14 & $14 \cdot 1$ & 1.94 & 8 & $15 \cdot 0$ & $2 \cdot 31$ \\
\hline $5-\mathrm{CHOH}_{4} \mathrm{~F}$ & 21 & $7 \cdot 6$ & $1 \cdot 42$ & 10 & $7 \cdot 5$ & $1 \cdot 66$ & 16 & $9 \cdot 4$ & $1 \cdot 69$ & 10 & $9 \cdot 2$ & $1 \cdot 44 \mathrm{C}$ \\
\hline $\mathrm{H}_{4} \mathrm{~F}$ & 14 & $5 \cdot 6$ & $1 \cdot 18$ & 8 & $6 \cdot 5^{*}$ & 0.89 & 12 & $11 \cdot 1$ & 1.89 & 8 & $12 \cdot 8^{*}$ & $2 \cdot 02$ \\
\hline $10-\mathrm{CHOH}_{4} \mathrm{~F}$ & 8 & $5 \cdot 2$ & $1 \cdot 35$ & 8 & $6 \cdot 2$ & $1 \cdot 22$ & 8 & $8 \cdot 6$ & 1.62 & 8 & $9 \cdot 4$ & $1 \cdot 89$ \\
\hline $5-\mathrm{CH}_{3} \mathrm{H}_{4} \mathrm{~F}$ & 14 & $8 \cdot 3$ & $1 \cdot 74$ & 8 & $6 \cdot 3^{*}$ & $1 \cdot 55$ & 12 & $16 \cdot 9$ & $3 \cdot 24$ & 8 & $14 \cdot 5$ & $2 \cdot 86$ \\
\hline F & 8 & $7 \cdot 5$ & $1 \cdot 39$ & 4 & $6 \cdot 7$ & $1 \cdot 17$ & 8 & $14 \cdot 0$ & $1 \cdot 83$ & 4 & $14 \cdot 7$ & $2 \cdot 13$ \\
\hline $\mathrm{OHCbl}+5 \mathrm{CHOH}_{4} \mathrm{~F}$ & 14 & $7 \cdot 7$ & $1 \cdot 76$ & 8 & $7 \cdot 5$ & $1 \cdot 20$ & 12 & $9 \cdot 2$ & $1 \cdot 84$ & 8 & $8 \cdot 9$ & $1 \cdot 83$ \\
\hline $\mathrm{OHCbl}+\mathrm{H}_{4} \mathrm{~F}$ & 14 & $3 \cdot 0$ & 1.03 & 8 & $7 \cdot 4^{*}$ & $1 \cdot 33$ & 12 & $7 \cdot 5$ & $3 \cdot 39$ & 8 & $13 \cdot 5^{*}$ & $2 \cdot 90_{c}$ \\
\hline $\mathrm{OHCbl}+10 \mathrm{CHOH}_{4} \mathrm{~F}$ & 8 & $4 \cdot 7$ & $1 \cdot 47$ & 8 & $7 \cdot 4^{*}$ & $1 \cdot 26$ & 8 & $9 \cdot 9$ & $3 \cdot 47$ & 8 & $12 \cdot 6^{*}$ & $2.58 \frac{\mathrm{C}}{\mathrm{D}}$ \\
\hline $\mathrm{OHCbl}+5 \mathrm{CH}_{3} \mathrm{H}_{4} \mathrm{~F}$ & 14 & $8 \cdot 2$ & $1 \cdot 73$ & 8 & $6 \cdot 6^{*}$ & $1 \cdot 67$ & 11 & $16 \cdot 7$ & $3 \cdot 16$ & 8 & $14 \cdot 1$ & 1.56 \\
\hline $\mathrm{OHCbl}+\mathrm{F}$ & 6 & $7 \cdot 5$ & $1 \cdot 34$ & 4 & $7 \cdot 2$ & $1 \cdot 89$ & 8 & $13 \cdot 1$ & $1 \cdot 64$ & 4 & $13 \cdot 8$ & 1.55 \\
\hline
\end{tabular}

*Significant difference between values for $\mathbf{A}$ and $\mathbf{B}$. 
patients with megaloblastic anaemia due to $B_{12}$ deficiency (Fig. 4) or to folate deficiency (Fig. 5). It is difficult to say whether variation in the results in individual patients under the 2 sets of conditions could be due to such a factor. It would be scientifically more valid to include the additive in the control.

\begin{tabular}{|c|c|c|c|}
\hline \multirow[b]{2}{*}{$\mathrm{Nil}$} & $\begin{array}{l}\text { Air-breathing } \\
\text { controls }\end{array}$ & \multicolumn{2}{|c|}{$\begin{array}{l}\text { Three hours' } \\
\text { exposure to } \mathrm{N}_{2} \mathrm{O}\end{array}$} \\
\hline & 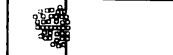 & & 8: \\
\hline $\mathrm{OH}-\mathrm{Cbl}+\mathrm{H}_{4} \mathrm{~F}$ & . & $\cdots+$ & $\begin{array}{l}\cdots \\
8 \text { xor }\end{array}$ \\
\hline $\mathrm{OH}-\mathrm{Cbl}+\mathrm{lO}-\mathrm{CHO}-\mathrm{H}_{4} \mathrm{~F}$ & ste & $\cdots$ & 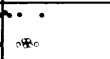 \\
\hline $\mathrm{H}_{4} \mathrm{~F}$ & ant & & - \\
\hline 10- $\mathrm{CHO}-\mathrm{H}_{4} \mathrm{~F}$ & w. & $*$ & 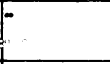 \\
\hline $5-\mathrm{CHO}-\mathrm{H}_{4} \mathrm{~F}$ & $\sqrt{4}$ & & .. \\
\hline $\mathrm{OH}-\mathrm{Cbl}+5-\mathrm{CHO}-\mathrm{H}_{4} \mathrm{~F}$ &. & $\cdots \infty$ & \\
\hline $\mathrm{OH}-\mathrm{Cbl}$ & - & & $-\infty$ \\
\hline $\mathrm{F}$ & .4 & & 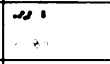 \\
\hline $\mathrm{OH}-\mathrm{Cbl}+\mathrm{F}$ & 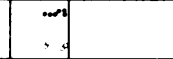 & & $m$ \\
\hline $5-\mathrm{CH}_{3}-\mathrm{H}_{4} \mathrm{~F}$ & -4 & & $\begin{array}{l}+1 \ldots . \\
-1\end{array}$ \\
\hline $\mathrm{OH}-\mathrm{CbI}+5-\mathrm{CH}_{3}-\mathrm{H}_{4} \mathrm{~F}$ & 44 & & 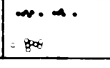 \\
\hline & $\begin{array}{lll} & 1 & \\
0 & 10 & 20\end{array}$ & 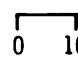 & $\begin{array}{ll} & 1 \\
0 & 20\end{array}$ \\
\hline
\end{tabular}

FIg. 3. The results of the dU suppression tests in normal rat marrows and in marrows from rats in whom cobalamin had been inactivated by inhaling a mixture of oxygen and nitrous oxide $(1 / 1)$. In the tests shown as a filled circle, folate or cobalamin was not added to the control tubes which had marrow and thymidine only. In the tests shown by the unfilled circle, folate and/or cobalamin were added to control tubes as well as to tubes containing first $\mathrm{dU}$ and then ${ }^{3} \mathrm{H}$-thymidine.

\section{Discussion}

The effect of folates and cobalamins on the uptake of labelled thymidine may be complex and an attempt to account for these findings in terms of the known pathways involving these cofactors may be an oversimplification (Pelliniemi and Beck, 1980). Nevertheless, in patients with such deficiencies, correction of the defect must play a significant role. The results are least complex in human marrow because the additives had no demonstrable effect on human marrow from haematologically normal subjects. Nor did the addition of hydroxocobalamin to either $\mathrm{B}_{12}$-deficient or folate-deficient marrow (in the absence of added dU) have any significant effect. All the folate additives produced significant

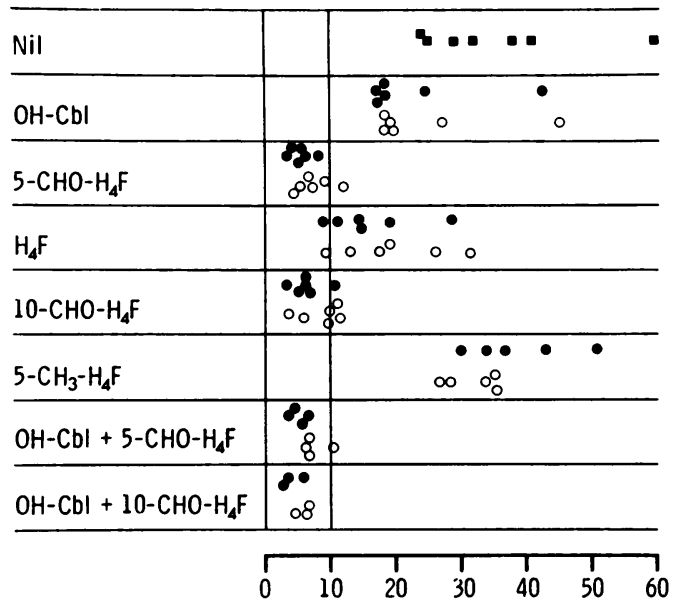

dU suppression test in $\mathrm{Cbl}$ deficiency - \%

FIG. 4. The results of the dU suppression test in human marrow from patients with megaloblastic anaemia due to cobalamin deficiency. In the tests indicated by the filled circles cobalamin or folate was not added to controls. In the tests indicated by the unfilled circle, folate and/or cobalamin was added to all tubes including controls.

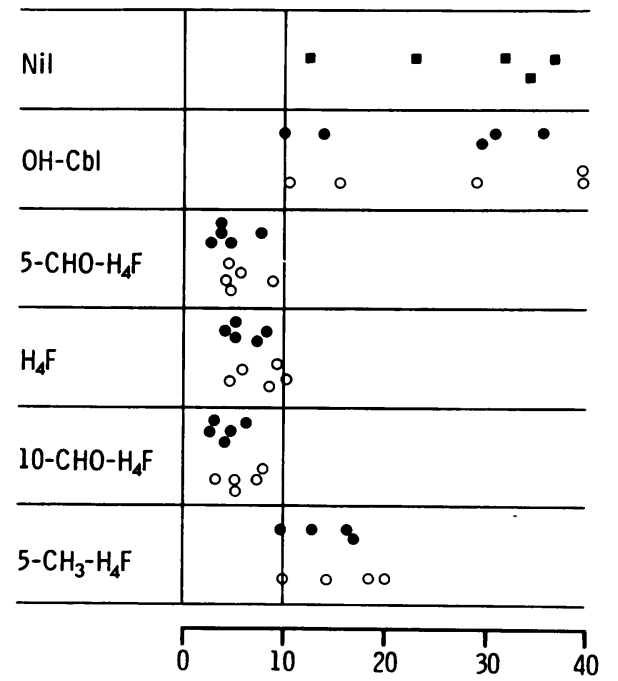

dU suppression test in folate deficiency - \%

FIG. 5. The results of the dU suppression test in human marrow from patients with megaloblastic anaemia due to folate deficiency. In the tests indicated by the filled circle, cobalamin or folate was not added to controls. In the tests indicated by the unfilled circle, folate and/or cobalamin was added to all tubes including controls. 
effects on the utilization of exogenous thymidine. The formylfolates and tetrahydrofolates all reduced the amount of thymidine taken up. In $\mathrm{B}_{12}$ deficiency, tetrahydrofolate had a smaller though not statistically significant effect than the other compounds, an effect also noted in the dU suppression test. A plausible explanation for the effect of folates is that they facilitated the methylation of endogenous $\mathrm{dU}$ into deoxythymidine and so reduced thymidine requirements.

However, the result of the dU suppression test remained valid despite adding folates to controls. This implies that the methylation of endogenous $\mathrm{dU}$ even after addition of the cofactor, was insufficient to meet thymidine requirements in megaloblastic marrows. Possibly the pool of endogenous $\mathrm{dU}$ was reduced and exogenous $\mathrm{dU}$, as added in the dU suppression test and within the time allowed for incubation, was not methylated as efficiently to thymidine, as was the case in normal marrows.

The results following the addition of methylfolate is of particular interest because while it reduced the uptake of thymidine in folate-deficient marrows it increased the uptake in cobalamin-deficient marrows. Indeed, if any more procedures were needed to differentiate $\mathbf{B}_{12}$ and folate deficiency, these observations would form the basis for such a test. On the same premise methylfolate prevented the methylation of endogenous dU. The methyl group of methylfolate can only be donated to homocysteine to form methionine and itself cannot serve as the methylating agent for dU. Nor does it control the enzyme, methylenetetrahydrofolate reductase, which forms methylfolate from methylenefolate and hence may influence the availability of the single carbon unit donor to deoxyuridine. This step is controlled by the level of S-adenosylmethionine (Kutzbach and Stokstad, 1967). Another hypothetical explanation for the effect of methylfolate is that it blocks folate receptors on the cell surface and prevents transport of folate across cell membranes. Cobalamin deficiency and cobalamin inactivation by $\mathrm{N}_{2} \mathrm{O}$, both interfere with tissue uptake of folates. The mechanism of this is unexplored as yet but gross abnormalities in red cell membranes in megaloblastic patients have been described (Ballas, 1978).

The results with rat marrows are more complex since essentially the same pattern of results appeared with normal and with $\mathrm{N}_{2} \mathrm{O}$-treated marrows. Thymidine uptake was decreased significantly by both 10-formylfolate and tetrahydrofolate. If availability of folate was a limiting factor in haemopoiesis in normal rats then this would account for the similarity in pattern of results in control and $\mathrm{N}_{2} \mathrm{O}$-treated groups. Indeed this may be the case. In both groups, the addition of methyltetrahydrofolate increased the use of exogenous thymidine significantly, an effect noted only in $\mathrm{B}_{12}$-deficieig marrow in man. A possible explanation has been mentioned.

Wickramasinghe and Saunders (1979) have suggested that the omission of the additive in the control tube in the dU suppression test is a defect its design. While in agreement with this viewpoint $\bar{g}$ should also be stated that such an addition did ne make a significant difference to the results with human material. The results with this test in megaloblastic anaemia are so satisfactory that it woula have been surprising to find a major anomaly in its design. Nevertheless there may be marginal diffe ences in some individual cases. The advantage fully matched controls is evident in the results wit rat marrows. With marrows from healthy rats the use of matched controls brought all the mean valueg with normal marrows to within a very narrow range and this is the justification for using this base interpreting data in $\mathrm{N}_{2} \mathrm{O}$-treated animals. Unlike the test with human marrow, comparing matcheg and unmatched control resulted in significant differences in the result when tetrahydrofolat@ 10-formyltetrahydrofolate and 5-methyltetrahydrof folate were added in the performance of the d suppression test.

\section{References}

BAIN, B. (1975) Folate requirement for blast cell this formation in mixed leukocyte cultures. Cell Immunotog 15, 237.

Ballas, S.K. (1978) Abnormal erythrocyte membrare protein pattern in severe megaloblastic anemia. Journg of Clinical Investigation, 61, 1097.

Chanarin, I. (1979) The Megaloblastic Anaemias, 2nd ed? p. 266. Blackwell Scientific Publications, Oxford.

Deacon, R., Chanarin, I., Perry, J. \& LUmb, M. (198@ Impaired deoxyuridine utilization in the $B_{12}$-inactivated rat and its correction by folate analogues. Biochemic and Biophysical Research Communications, 93, 516.

Killman, S-A (1964) Effect of deoxyuridine on incorporatie of tritiated thymidine: difference between normoblas and megaloblasts. Acta medica scandinavica, 175, 483.

KutzBaCH, C. \& STokstad, E.L.R. (1967) Feedbach inhibition of methylenetetrahydrofolate reductase in rat liver by $\mathrm{S}$-adenosylmethionine. Biochimica et biophysi@ acta, 139, 217.

Metz, J., Kelly, A., Swett, V.C., Waxman, S. \& HerberJ V. (1968) Deranged DNA synthesis by bone marrow from vitamin $\mathrm{B}_{12}$-deficient humans. British Journal $\not$ Haematology, 14, 575.

Pelliniemi, T-T \& BeCK, W.S. (1980) Biochemical mechianisms in the Killman experiment. Critique of the deox uridine suppression test. Journal of Clinical Investigation, 65, 449.

RABINOWITZ, J.C. (1963) Preparation and properties of 10-methenyltetrahydrofolic acid and 10-formyltetrahydrofolic acid. Methods in Enzymology, 6, 166.

Rogers, H.J. \& Lietman, P.S. (1977) Effect of folate and folinate on ${ }^{3} \mathrm{H}$-thymidine incorporation by transformin human lymphocyte in vitro. Experientia, 33, 671.

Wickramasinghe, S.N. \& SAUNDERS, J.E. (1979) A fault in the design of deoxyuridine suppression test. Clinict and Laboratory Haematology, 1, 69. 